\title{
Financial Engineering and Its Role in the Growth and Development of Islamic Banking in Palestine
}

\author{
Dr. Amer S. Jaber \\ Phd - Islamic finance \\ Tel: 97-059-937-4274Ｅ-mail: amer.jaber2010@hotmail.com
}

Received: August 27, 2018 Accepted: Oct. 21, $2018 \quad$ Published: December 1, 2018

doi:10.5296/ajfa.v10i2.13690 URL: https://doi.org/10.5296/ajfa.v10i2.13690

\begin{abstract}
The study aimed to identify the role of financial engineering in the growth and development of Islamic banking in Palestine; this is through the acknowledgment of the role of the Sharia Supervisory Board represented by the jurisprudential opinions on new Islamic products and tools. Moreover, the role of the regulations and instructions issued by the Palestine Monetary Authority (PMA) concerning Islamic banks. In addition to the impact of experience and employees' training, as well as the impact of modern technology on the growth and development of Islamic banking in Palestine.
\end{abstract}

The researcher used the analytical descriptive approach to reach conclusions and recommendations that can be generalized. The study population was employees working at Islamic banks in Palestine, who are (1049) employees. The sample for the study targeted 315 employees, which consists $30 \%$ of the total population. The tool used for the study was questionnaires distributed on the sample to collect preliminary data. The number of respondents was (258) employees which composes $81 \%$ of the sample.

The study has reached many conclusions, and the following are the most important ones: The views of the Sharia Supervisory Board in the banks operating in Palestine play a major role in the growth and development of Islamic banking, while the other areas play a moderate role in the growth and development of Islamic banking in Palestine. The study recommended the need to spread the culture of electronic Islamic banking, and the need to update the regulations and instructions governing Islamic banking. In addition to the need for cooperation and coordination between the Sharia Supervisory Boards of the banks and the unified authority that is affiliated with the PMA.

Keywords: Islamic banks, Financial Engineering, Palestine. 


\section{Introduction}

Islamic banks in Palestine seek to provide a range of financial services to their clients, through Islamic financial instruments, either modern or original. This is in order to differentiate themselves from the traditional banking sector and attract more customers, which is beneficial to the Islamic banks in Palestine, by managing its liquidity in a profitable and glorious way, which is known as financial engineering.

The International Financial Engineers Association (IFE) has defined the concept of financial engineering as "the process by which the financial instruments used by the financial institution are developed, as well as the application of the financial theory in an innovative manner and finding solutions to the financial problems that the institution suffers through finding financial instruments that benefit the institution Finance”. (Kunduz, 2007, p. 10)

Islamic banking in Palestine is considered a banking system that adheres to the provisions of the Islamic Sharia. Unlike other existing banking systems, it considers the introduction of banking services as the embodiment of Islamic principles to reach a functional and economic society within the limits of Islamic law. A banking institution committed in all transactions and investment activities and management of all its work Islamic law and purposes as well as the objectives of the Islamic community internally and externally. (Rifai, 2004, p. 20)

\section{Methodology}

The study was based on the descriptive analytical approach. The Secondary data were obtained from relevant books and financial reports. While the primary data were collected, through using a questionnaire, from the study population and were analyzed statistically to obtain the results of the study. The questionnaire was a primary data collection tool that aimed to identifying the role played by financial engineering in the growth and development of Islamic banking.

Islamic banks in Palestine should re-formulate their tools and products, or create new ones in a creative way, in line with the global developments in the field of Islamic banking. This can be achieved through using the financial engineering tools and products, and the result is exploitation of the opportunities inherent, especially in light of the rapid development and renewal in the sector. Islamic banks, hence the problem of the study, which is the question of the following questioning:

What is the role of financial engineering in the growth and development of Islamic banking in Palestine?

There are several sub-questions that the study seeks to answer:

1. What is the role of the Sharia Supervisory Board represented by the jurisprudential opinions on the new Islamic products in the growth and development of Islamic banking in Palestine?

2. What is the role of the regulations and instructions issued by the Palestinian Monetary Authority concerning Islamic banks in the growth and development of Islamic banking? 
3. What is the impact of experience and staff training on the growth and development of Islamic banking in Palestine?

4. What is the impact of modern technology on the growth and development of Islamic banking in Palestine?

This study aims to identify the role of The Sharia Supervisory Board to devise creative solutions to the problems of financing granted by the Palestinian Islamic banks. As well as to recognize the role of the regulations and instructions issued by the PMA concerning Islamic banks in the growth and development of Islamic banking. Also recognizing the impact of experience and employees' training on the growth and development of Islamic banking in Palestine. In addition to learning about the impact of modern technology on the growth and development of Islamic banking in Palestine.

The importance of the study is in its contribution to highlighting the importance of financial engineering in the development of Islamic banking in Palestine and its attempt to uncover modern methods for the development and growth of Islamic banking in Palestine. The study aims to enhance the studies and researches for those interested in the development of Islamic banking in Palestine. The results of the study are expected to reach an important source for the Islamic banks in Palestine to rely on them to develop their tools and products to serve the Palestinian society.

\section{Hypotheses of the study}

The following hypotheses were formulated in an attempt to answer the questions posed by the study:

3.1 There is a statistically significant relationship between the clarity of the opinion of the Shari'ah Supervisory Board of the Palestinian Islamic Banks and the growth and development of Islamic banking in Palestine.

3.2 There is a statistically significant relationship between the restrictions on regulations and instructions issued by the Palestinian Monetary Authority concerning Islamic banks and the growth and development of Islamic banking.

3.3 There is a statistically significant relationship between experience and employees' training and the growth and development of Islamic banking in Palestine.

3.4 There is a statistically significant relationship between the use of modern technology and the growth and development of Islamic banking in Palestine.

\section{Society and Study Sample}

The society of the study is composed of employees of the three Islamic banks operating in Palestine. The number of employees was (1049) employees until the end of 2017 according to the annual report 2017 issued by each bank. A stratified sample targeted 30\% of the society, the sample size was (315) employees. The following table shows the society and the sample of the study in numbers: 
Table 1. Distribution of the society and sample of the study

\begin{tabular}{|l|c|c}
\hline \multicolumn{1}{|c|}{$\begin{array}{c}\text { NAME OF ISLAMIC } \\
\text { BANK }\end{array}$} & $\begin{array}{c}\text { STUDY SOCIETY / NUMBER } \\
\text { OF EMPLOYEES }\end{array}$ & SAMPLE STUDY 30\% \\
\hline Palestine Islamic Bank & 568 & 170 \\
\hline Arab Islamic Bank & 411 & 123 \\
\hline Safa Bank & 70 & 21 \\
\hline Total & $\mathbf{1 0 4 9}$ & $\mathbf{3 1 5}$ \\
\hline
\end{tabular}

\section{Statistical treatments}

After the data was collected and processed statistically using the statistical program (SPSS) using the following statistical treatments:

5.1 Calculations, percentages, and repetitions to calculate the relative weight of the subjects and areas of the study instrument

5.2 Examining the stability of the questionnaire using the formula Alpha Kronbach.

\section{Literature Review}

\subsection{Previous studies}

6.1.1 Sabreena Rashad, 2017, "Islamic Financial Engineering as a Mechanism to Provide Islamic Banking Financing"

This study aimed to understand the role of Islamic financial engineering in providing Islamic banking financing in order to meet the diverse financial needs of various concerned parties, as well as clarifying the concept of Islamic financial engineering and its scientific and practical importance in the growth and development of Islamic finance.

The researcher used the analytical descriptive approach to collect data on financial engineering and Islamic banking financing. The researcher adopted the consolidated financial reports issued by the International Islamic Financial Market to access the preliminary data for analysis and access to the results, the most important of which is that Islamic Engineering supports Islamic banking by providing products and tools, and that these products are generated by innovation by simulation and not by real innovation.

The study recommended the need to move away from imitating the products of conventional banks to create new products, and the need to develop and control the methods of Islamic finance depending on the specialists in the subject of financial engineering, in addition to the need to establish units for research and development in financial institutions.

6.1.2 Bonkab, 2016, "The Role of Islamic Financial Engineering in Risk Management of Islamic Financing Formulations - A Case Study of Al Baraka Bank of Algeria"

This study aimed to identify the role of Islamic financial engineering in managing the risks of the financing formulas of Al Baraka Algeria Bank. The researcher used the analytical descriptive approach for studying the concepts of risk management and financial engineering. 
The researcher also used the case study to clarify the mechanism of risk management at $\mathrm{Al}$ Baraka Bank of Algeria.

The study concluded that Islamic financial engineering contributes to the risk management of Al Baraka Bank of Algeria, but this contribution is limited to the sales formulas related to Murabaha and leasing, and the regulations and instructions issued by the regulatory authorities in Algeria regarding the Islamic banking business applied by Al Baraka Bank are effective and serve Islamic finance. Moreover, the opinion of the Sharia Supervisory Board has a significant impact on the growth and development of the services of the bank.

The study recommended the need for Al Baraka Bank to adjust some of its procedures in risk management, as well as the need to follow up the funds granted to customers on an ongoing basis.

\subsubsection{Moenis, 2016 "The rules of engineering Islamic financial products analytical study"}

This study aimed to prove the role of financial engineering in finding new financing products that meet the needs of the customers. The study has addressed the concept of Islamic financial products engineering and the need for them. It concluded that the engineering of Islamic finance products was based on several rules that gain advantages and specificities from conventional financing. The rules of product engineering are the engineering of finance products to achieve the goal of Islamic finance and the legitimacy of the contractual system. The production is the basis for the benefit contributed by the financing product. The efficiency criterion in Islamic financial products is to reduce costs to achieve economic efficiency and credibility of legitimacy.

The study recommended the need to allocate specialized studies to each of the rules of financial engineering, which provides a clearer vision of Islamic finance in the context of its ability to meet the wishes and needs of customers.

\subsubsection{Omrana \& Aboulaich (2016) "Islamic Financial Engineering Al Arboun Sale"}

The aim of this study is to clarify the possible alternatives to the sale of mortgages under financial engineering, as well as to identify the role of financial engineering in the creation of Islamic financial services.

The study concluded that the sale of mortgages can be an Islamic alternative in the case of traditional buying under sound management of potential risks. The study recommended that the Islamic finance operations should be performed separately and continuously to ensure the development and innovation, to keep abreast of the technological progress in Islamic banking.

\subsubsection{Kok (2014), "Derivative products and innovation in Islamic finance"}

This study aimed to highlight the possibility of organizing an Islamic option that includes an element of risk participation rather than risk transfer through what is known as innovation and financial engineering. The researcher used the analytical descriptive method to examine the possibility of forming an Islamic option to share the risks between the promise and 
Murabaha. The study relied on bi-period results.

The study concluded that the results obtained are based on the final trend of the market. The study presented arguments for the adoption of risk sharing, compared to the risk transfer methodology, when it comes to structuring management tools.

The study recommended the use of Islamic financial architecture as a modern method of organizing risk management in Islamic finance, as well as keeping abreast of the technological developments of the markets and financial transactions, as they are important in reducing the risk ratio of institutions.

6.1.6. Ginanjar, 2013, "Islamic Financial Engineering: Comparative Study Agreements in Islamic Capital Market in Malaysia and Indonesia"

This study aimed to provide a discussion of Islamic financial engineering in terms of its practice in the Indonesian Capital Market and the Malaysian Capital Market and compare them; in order to verify whether the regulator can play an effective role in achieving Islamic demands. The researcher used the analytical descriptive method to study the market response. During the analysis of the regulation of the Islamic capital market in the Middle East countries.

The study concluded that the growth in the Islamic capital market in the Malaysian capital market is higher than that of the Indonesian capital market due to the use of Islamic financial engineering for modern technology and the expertise of its managers and the resulting regulation of Islamic capital. Islamic Capital Market in Indonesia to compete with regional markets.

\subsection{The Situation of This Study from Previous Ones}

It is clear from the analysis of previous studies that they addressed mainly the concept of innovation and Islamic financial engineering and its reflection on Islamic banks, including the application of financial engineering as a tool to reduce risk in some financing tools. The majority of the researchers in the previous studies used the descriptive method to analyze financial data of some banks, Content Analysis.

As for the current study, it is distinguished from the scientific point of view, that it is one of the few studies that discussed the subject of financial engineering and its role in the development of Islamic banking in Palestine. The study also selects a study society that touches upon the practical reality of Islamic banking in Palestine.

\section{The Tool Study}

The researcher used the questionnaire as a tool for gathering information and reaching the objectives of the study. A number of previous studies and tools were used. A special questionnaire was developed to measure the role of financial engineering in the development and growth of Islamic banking in Palestine. The second section included paragraphs that measure the role of each field in the development and growth of Islamic banking in Palestine, the number of these paragraphs was (28) were addressed to employees in Islamic banks in 


\section{Macrothink}

Asian Journal of Finance \& Accounting

ISSN 1946-052X

2018, Vol. 10, No. 2

Palestine. The questionnaire was distributed from electronically on the study sample, and the total number of respondents was (258), which composes $81 \%$ of the selected sample.

\section{Description of Personal Respondents}

Table (2) shows a description of the personal factors of the sample of the study:

It is clear from Table (2) that the majority of the study sample was for the age group from 25 years to 45 years. Which indicates the high percentage of young people working in Palestinian Islamic banks, and $97 \%$ have majors in finance, banking and accounting only $7 \%$ of the sample had scientific qualifications related to Islamic banks and finance, this indicates that the Palestinian universities lack Islamic financial specialization.

The functional characteristics of the study sample were the largest proportion of the head of department and director of department and other names without that. Which indicates that the members of the sample of the study have the ability to answer the questionnaire professionally and objectively. And the number of years of experience of the study sample we find that the majority of those who have years of experience from 5 to 15 years. indicating that they have sufficient knowledge in the subject of the study.

Table 2. Frequencies and percentages for the personal variables of respondents

\begin{tabular}{|c|c|c|c|}
\hline Variable & Classification & Frequency & $\%$ \\
\hline \multirow[t]{4}{*}{ Age } & Under 25 years & 31 & 12 \\
\hline & From 25 years to less than 35 years & 127 & 49 \\
\hline & From 35 to 45 years old & 89 & 34 \\
\hline & 45 and above & 11 & 4 \\
\hline \multirow[t]{3}{*}{ Qualification } & Diploma or less & 8 & 3 \\
\hline & Bachelor & 179 & 69 \\
\hline & Master and above & 71 & 28 \\
\hline \multirow[t]{4}{*}{ Specialization } & Accounting & 65 & 25 \\
\hline & Banking and Financial Sciences & 71 & 28 \\
\hline & Islamic banks & 18 & 7 \\
\hline & Economy & 41 & 16 \\
\hline
\end{tabular}




\begin{tabular}{|c|c|c|c|}
\hline & Business Administration & 48 & 19 \\
\hline & Other & 15 & 6 \\
\hline \multirow[t]{6}{*}{ Job title } & general manger & 1 & 0 \\
\hline & Deputy General Manager & 1 & 0 \\
\hline & assistant of a general manager & 2 & 1 \\
\hline & Director & 43 & 17 \\
\hline & Head of the Department & 59 & 23 \\
\hline & Other & 152 & 59 \\
\hline \multirow[t]{6}{*}{ Years' experience } & 5 years and less & 127 & 49 \\
\hline & From 5 to less than 10 years & 81 & 31 \\
\hline & From 10 to less than 15 years & 27 & 10 \\
\hline & From 15 to less than 20 years & 13 & 5 \\
\hline & From 20 to 25 years & 7 & 3 \\
\hline & 25 years and over & 3 & 1 \\
\hline \multicolumn{2}{|c|}{ The sum of each variable } & 258 & $\% 100$ \\
\hline
\end{tabular}

\section{Stability of the Tool}

Stability of the tool was tested by Cronbach Alpha Coefficient test; Table (3) shows the following: 
Table 3. Internal stability coefficients in the Alpha Cronbach on the different fields of resolution and on the total score

\begin{tabular}{|l|c|c|}
\hline Variable & $\begin{array}{c}\text { Number of } \\
\text { paragraphs }\end{array}$ & $\begin{array}{c}\text { Cronbach } \\
\text { Alfa }\end{array}$ \\
\hline $\begin{array}{l}\text { The clarity of the opinion of the Sharia Supervisory Board } \\
\text { on the Palestinian Islamic Banks }\end{array}$ & 8 & 0.75 \\
\hline $\begin{array}{l}\text { Restrictions on regulations and instructions issued by the } \\
\text { Palestinian Monetary Authority }\end{array}$ & 7 & 0.89 \\
\hline $\begin{array}{l}\text { Experience with the employees of Islamic banks in } \\
\text { Palestine and their training }\end{array}$ & 6 & 0.77 \\
\hline use of modern technology & 7 & 0.79 \\
\hline all variable & $\mathbf{2 8}$ & $\mathbf{0 . 7 8}$ \\
\hline
\end{tabular}

It is clear from table(3) that the stability coefficients of the different areas of the $\alpha$-Cronbach resolution on the axes range from 0.75 to 0.89 , thus reflecting the consistency of the resolution paragraphs, which enables them to measure and examine the questions that the study went to.

All values in table 3 were $>0.60$ that means a stability of the tools (scatter 19), it thus reflects the stability of the questionnaire paragraphs, enabling them to measure and examine the questions that the study has gone through.

The scale was designed based on a five-dimensional Likert scale. The paragraphs were built in a positive direction and weights were given to the paragraphs as follows: Strongly agree: five degrees, agree: four degrees, neutral: three degrees, Disagree: two degrees, strongly disagree: one degree. The default is medium (3) which can be found by calculating the average of the previous options $(5+4+3+2+1) \div 5$.

Table 4. Estimating the level of role of financial engineering in the development and growth of Islamic banking in Palestine

\begin{tabular}{|c|c|c|}
\hline Range & $\%$ & Estimate the level of the role \\
\hline less than 3.44 & $\% 68.8$ less than & very low \\
\hline $3.82-3.44$ & $\% 76.4-68.8 \%$ & Low \\
\hline $4.21-3.83$ & $\% 84.2-76.5$ & Moderate \\
\hline $4.60-4.22$ & $\% 92.0-84.3$ & High \\
\hline 4.61 and above & More than $92 \%$ & very high \\
\hline
\end{tabular}

\section{Hypotheses}

\section{1 test of First hypothesis}

There is a statistically significant relationship between the role of the Sharia Supervisory Board represented by the jurisprudential opinions about new Islamic products and products and the growth and development of Islamic banking in Palestine. 


\section{Macrothink}

Table (5) shows that all grouped items have a mean of 4.37 , is the larger of about 1.37 average defaults (3). This means that this hypothesis is accepted. And there is a statistical relationship between the clarity of the opinion of the Sharia Supervisory Board of the Palestinian Islamic Banks and the growth and development of Islamic banking in Palestine.

It is clear from the data of table (5) that paragraph (8) was ranked first in terms of ranking, with an average of 4.76 and a (\%95.4) of Islamic Bank in Palestine with regard to traditional and Islamic financing instruments. The researcher connects this result with the requirements of the Palestinian Monetary Authority, the need to provide sufficient expertise in the Sharia Supervisory Board of the Islamic Bank. The Monetary Authority shall study the scientific qualifications of the members and the expertise available to them before approving the members of the Authority. Right to infringe the Sharia Supervisory Board.

The table also indicates that paragraph (4) was ranked last in terms of ranking, with an average of (3.53) and a (\%69.3) in low order. The researcher believes that this result is consistent with the actual reality of the role of the Sharia Supervisory Board. The legitimacy of tools and banking services and their approval of Islamic law. And the control of implementation is the functions of the auditor or the legitimate observer. Which is the link between the Sharia Supervisory Board and the employees of the bank. 


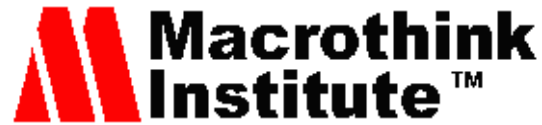

Table 5. Arithmetical averages, standard deviations and percentages of the clarity of the opinion of the Shari'ah Supervisory Board of the Palestinian Islamic Banks.

\begin{tabular}{|c|c|c|c|c|c|}
\hline No & Paragraph & $\begin{array}{c}\text { arithmeti } \\
\text { c } \\
\text { means }\end{array}$ & $\begin{array}{l}\text { standard } \\
\text { deviations }\end{array}$ & $\%$ & $\begin{array}{c}\text { relative } \\
\text { importanc } \\
\text { e }\end{array}$ \\
\hline 8 & $\begin{array}{l}\text { Members of the Sharia Supervisory } \\
\text { Board at the Bank have sufficient } \\
\text { expertise on traditional and Islamic } \\
\text { financing instruments. }\end{array}$ & 4.76 & 0.44 & 95.4 & very high \\
\hline 3 & $\begin{array}{l}\text { The opinions of the Sharia Supervisory } \\
\text { Board for your bank are clear and } \\
\text { understandable to all employees of the } \\
\text { bank. }\end{array}$ & 4.72 & 0.46 & 94.4 & very high \\
\hline 6 & $\begin{array}{l}\text { Members of the Sharia Supervisory } \\
\text { Board are constantly updated. }\end{array}$ & 4.68 & 0.69 & 93.6 & very high \\
\hline 7 & $\begin{array}{l}\text { The number of members of the Sharia } \\
\text { Supervisory Board at the Bank is } \\
\text { appropriate for the size of the } \\
\text { instruments used. }\end{array}$ & 4.68 & 0.69 & 93.6 & very high \\
\hline 5 & $\begin{array}{l}\text { The Bank shall ensure the independence } \\
\text { of the Sharia Supervisory Board from } \\
\text { the executive management, and shall be } \\
\text { subordinate to the Board of Directors. }\end{array}$ & 4.64 & 0.49 & 92.8 & very high \\
\hline 2 & $\begin{array}{l}\text { The opinions of the Sharia Supervisory } \\
\text { Board for your bank are in line with the } \\
\text { standards issued by the Accounting and } \\
\text { Auditing Organization for Islamic } \\
\text { Financial Institutions. }\end{array}$ & 4.08 & 1.19 & 81.6 & moderate \\
\hline 1 & $\begin{array}{l}\text { The Sharia Supervisory Board of your } \\
\text { bank issues clear and binding } \\
\text { mechanisms to implement various } \\
\text { Islamic financing formulas. }\end{array}$ & 3.56 & 1.16 & 71.2 & Low \\
\hline 4 & $\begin{array}{l}\text { The Sharia Supervisory Board shall } \\
\text { ensure the implementation of the } \\
\text { Islamic financing formulas in } \\
\text { accordance with its prior opinion. }\end{array}$ & 3.53 & 1.2 & 69.3 & Low \\
\hline & All grouped items & 4.37 & 0.45 & 86.4 & high \\
\hline
\end{tabular}

In analyzing the above data, it is clear to us that this is in line with the study of (Boonakab, 2016) in which Sharia Supervisory Board opinion has a significant impact on the growth and development of the bank's services, and also agrees with the study of (Al Suwailem , 2007) in its recommendations to select the Sharia Supervisory Board very carefully because of this 
importance in the development of banks Islamic.

\subsection{Second Hypothesis}

There is a statistically significant relationship between the regulations and the instructions issued by the Palestinian Monetary Authority concerning Islamic banks and the growth and development of Islamic banking.

Table(6) shows that all grouped items have a mean of 4.01, is the larger of about 1.01 average default (3), which means that this hypothesis is accepted, and there is a statistical relationship between the regulations and the instructions issued by the Palestinian Monetary Authority concerning Islamic banks and the growth and development of Islamic banking.

Table (6) shows that paragraph (5) ranked first in terms of ranking, with an average of 4.68 and a (\%93.6) is in a very high order. This indicates that the difference between the legitimate opinions of the banks. The most important impediments to the development and growth of Islamic banks, and what the Palestinian Monetary Authority has set up to form a unified Sharia Supervisory Board is one of the fundamentals of the growth and development of Islamic banking in Palestine. This generates an atmosphere of competition under an agreed jurisprudential opinion to apply Islamic tools or banking services. .

The table also shows that paragraph (1) was ranked last in terms of ranking, with an average of 3.36 and $(\% 67.2)$. This is a true result. The work of the Islamic banks in Palestine is organized according to the fourth chapter of the Banking Act 2010.Table 5. Arithmetical averages, standard deviations and percentages of the promotional campaigns offered by Islamic banks in Palestine. 
Table 6. Arithmetical averages, standard deviations and percentages of the regulations and the instructions issued by the Palestinian Monetary Authority concerning Islamic banks.

\begin{tabular}{|c|c|c|c|c|c|}
\hline No & Paragraph & $\begin{array}{c}\text { arithmetic } \\
\text { means }\end{array}$ & $\begin{array}{c}\text { standard } \\
\text { deviations }\end{array}$ & $\%$ & $\begin{array}{c}\text { relative } \\
\text { importance }\end{array}$ \\
\hline 5 & $\begin{array}{l}\text { The formation of the unified Sharia } \\
\text { Supervisory Board by the Monetary } \\
\text { Authority is one of the most important } \\
\text { solutions related to the problem of } \\
\text { divergent jurisprudential views in } \\
\text { transactions. }\end{array}$ & 4.68 & 0.56 & 93.6 & Very high \\
\hline 3 & $\begin{array}{l}\text { The Monetary Authority helps Islamic } \\
\text { banks in Palestine to find innovative } \\
\text { solutions to the problems they face. }\end{array}$ & 4.52 & 0.59 & 90.4 & High \\
\hline 7 & $\begin{array}{l}\text { The Monetary Authority shall provide laws } \\
\text { and regulations regulating the work of } \\
\text { Islamic banks and shall comply with the } \\
\text { provisions of Islamic Sharia. }\end{array}$ & 4.48 & 82 & 89.6 & High \\
\hline 6 & $\begin{array}{l}\text { The Monetary Authority charges fines for } \\
\text { any illegal violations of the work of the } \\
\text { Islamic finance institutions in Palestine. }\end{array}$ & 4.16 & 0.94 & 83.2 & moderate \\
\hline 4 & $\begin{array}{l}\text { The Monetary Authority shall monitor and } \\
\text { monitors the activities of the Islamic banks } \\
\text { in Palestine and the extent to which they } \\
\text { apply the provisions of the Islamic Shari'a } \\
\text { on an ongoing basis. }\end{array}$ & 4.12 & 0.97 & 82.4 & moderate \\
\hline 2 & $\begin{array}{l}\text { The Monetary Authority holds educational } \\
\text { workshops on Islamic banking and its } \\
\text { modern financing tools. }\end{array}$ & 3.72 & 1.06 & 74.4 & Low \\
\hline 1 & $\begin{array}{l}\text { The PMA continuously updates regulations } \\
\text { and instructions in line with modern } \\
\text { Islamic banking standards. }\end{array}$ & 3.36 & 1.15 & 67.2 & Very low \\
\hline & All grouped items & 4.01 & 0.51 & 82.9 & Moderate \\
\hline
\end{tabular}

In analyzing the above data, we show that the result contradicts with the (Bonkab, 2016) study that the regulations and instructions issued by the regulatory authorities in Algeria regarding Islamic banking, which is implemented by Al Baraka Bank is effective and serves Islamic finance, but it agrees with the recommendations of the study (Ali and Naajah, 2013) the need to develop regulations and instructions governing work Islamic banking in line with progress in all fields.

\subsection{Third hypothesis}

There is a statistically significant relationship between experience and employees' training and the growth and development of Islamic banking in Palestine. 
Table (7) shows that all grouped items have a mean of 4.12, is the larger of about 1.12 average defaults (3), which means that this hypothesis is accepted, and there is a statistical relationship between experience and employees training and the growth and development of Islamic banking in Palestine.

Table (7) shows paragraph (5) ranked first in terms of ranking, with an average of 4.72 and $95.1 \%$ in a very high order. This shows that the executive management of Islamic banks in Palestine. The table also indicates that paragraph (4) was ranked last in terms of ranking, with an average of 3.28 and $65.6 \%$ in a low order.

Table 7. Arithmetical averages, standard deviations and percentages of the diversifying and developing the services of Palestinian Islamic banks

\begin{tabular}{|c|c|c|c|c|c|}
\hline No & Paragraph & $\begin{array}{c}\text { arithmetic } \\
\text { means }\end{array}$ & $\begin{array}{c}\text { standard } \\
\text { deviations }\end{array}$ & $\%$ & $\begin{array}{c}\text { relative } \\
\text { importance }\end{array}$ \\
\hline 5 & $\begin{array}{l}\text { The Executive Directorate issues an } \\
\text { indicative guide to the application } \\
\text { of new funding modalities. }\end{array}$ & 4.72 & 0.48 & 95.1 & Very high \\
\hline 2 & $\begin{array}{l}\text { The management is keen to train all } \\
\text { employees of the bank on the } \\
\text { development and innovation in the } \\
\text { field of Islamic banking. }\end{array}$ & 4.32 & 0.69 & 86.4 & High \\
\hline 1 & $\begin{array}{l}\text { The bank has a department } \\
\text { specializing in developing financial } \\
\text { instruments and innovating Islamic } \\
\text { products. }\end{array}$ & 4.12 & 0.88 & 82.4 & moderate \\
\hline 6 & $\begin{array}{l}\text { Training workshops are held for all } \\
\text { employees of the Bank to publish } \\
\text { the findings of other countries in } \\
\text { the field of Islamic banking. }\end{array}$ & 4.08 & 0.91 & 81.6 & moderate \\
\hline 3 & $\begin{array}{l}\text { Participate in international } \\
\text { conferences and training courses on } \\
\text { developing Islamic tools and } \\
\text { products. }\end{array}$ & 3.76 & 1.2 & 75.2 & Low \\
\hline 4 & $\begin{array}{l}\text { Creative and innovative employees } \\
\text { are motivated by a financial reward } \\
\text { or a moral assessment }\end{array}$ & 3.28 & 1.17 & 65.6 & Very low \\
\hline & All grouped items & 3.72 & 0.48 & 81 & Moderate \\
\hline
\end{tabular}

In view of the table's data, we note that the result is in line with the study of Othman (2008), which concluded that Islamic banks in order to continue to innovate and develop their tools must seek to create the appropriate environment for financial institutions for development and innovation, such as motivating employees to innovate and develop and preserve the moral rights of the owner of the idea or innovation. 


\subsection{Fourth hypothesis}

There is a statistically significant relationship between the use of modern technology and the growth and development of Islamic banking in Palestine.

Table (8) shows that all grouped items have a mean of 3.72, is the larger of about 0.72 of average defaults (3), which means that this hypothesis is accepted, and there is a statistical relationship between the use of modern technology and the growth and development of Islamic banking in Palestine.

It is clear from the data of table (8) that paragraph (5) ranked first in terms of ranking, with an average of (4.56) and a percentage (92.8) is in a very high order. Dealing with ATMs, which reduces the effort and cost incurred by the bank because of regular banking operations through branch employees. The table also indicates that paragraph (7) ranked last in terms of order, with an average of 2.6 and $52 \%$ is by a very low order. These shows not motivate customers to deal with ATMs by imposing additional commissions.

Table 8. Arithmetical averages, standard deviations and percentages of use of modern technology.

\begin{tabular}{|c|l|c|c|c|c|}
\hline No & \multicolumn{1}{|c|}{ Paragraph } & $\begin{array}{c}\text { arithmetic } \\
\text { means }\end{array}$ & $\begin{array}{c}\text { standard } \\
\text { deviations }\end{array}$ & \% & $\begin{array}{c}\text { relative } \\
\text { importance }\end{array}$ \\
\hline 5 & $\begin{array}{l}\text { Your bank adopts the spread through } \\
\text { ATMs that offer check an deposit } \\
\text { services. }\end{array}$ & 4.56 & 0.48 & 92.8 & very high \\
\hline 3 & $\begin{array}{l}\text { The bank offers Sharia-compliant credit } \\
\text { cards }\end{array}$ & 4.32 & 0.69 & 86.4 & high \\
\hline 1 & $\begin{array}{l}\text { The bank offers its customers Internet } \\
\text { banking services for electronic payments }\end{array}$ & 4.12 & 0.88 & 82.4 & moderate \\
\hline 2 & $\begin{array}{l}\text { The bank provides smart phone } \\
\text { applications for financial transactions }\end{array}$ & 4.08 & 0.91 & 81.6 & moderate \\
\hline 4 & $\begin{array}{l}\text { The Bank relies on SMS to deploy its new } \\
\text { services }\end{array}$ & 3.96 & 0.79 & 79.2 & moderate \\
\hline 6 & $\begin{array}{l}\text { The customer requests electronic services } \\
\text { by attending the bank. }\end{array}$ & 3.72 & 0.98 & 74.4 & low \\
\hline 7 & $\begin{array}{l}\text { Your bank charges additional fees for } \\
\text { withdrawals and deposits made within } \\
\text { branches and through bank employees. }\end{array}$ & 2.6 & 0.87 & 52 & Very low \\
\hline \multicolumn{2}{|c|}{ All grouped items } & $\mathbf{3 . 7 2}$ & $\mathbf{0 . 4 8}$ & $\mathbf{7 8 . 4}$ & moderate \\
\hline
\end{tabular}

This is in line with the study of Omrana \& Aboulaich (2016), which recommended that the Islamic finance operations should be carried out separately and continuously to ensure the development, innovation and pace of technological progress in Islamic banking. 
Results

1. The overall degree of the role of financial engineering in the growth and development of Islamic banking in Palestine was medium, with the total percentage of respondents' answers to all paragraphs in all fields (82.1).

2. The results of the factors analysis showed that the most important factors to growth and development of Islamic banking in Palestine are ranked as important:

- First: the clarity of the opinion of the Sharia Supervisory Board of Islamic Banks in Palestine. The role of this field was high (86.4).

- Second: the restrictions and regulations issued by the Palestinian Monetary Authority (PMA). The role of this area was averaged (82.9).

- Third: the experience of the employees at Islamic banks in Palestine and their training. The role of this field was also average with an average of (81)

- Fourth: the application of modern technology in the Islamic banks in Palestine and the role of average and average arithmetic (78.4).

3. The percentage of young people working in Islamic banks in Palestine, where the majority of the study sample was for the age group from 25 years to 45 years.

4. The interest of Islamic banks to employ their scientific competencies, since $97 \%$ of the sample have academic qualifications bachelor or above.

\section{Recomendations}

1. To spread the culture of Islamic banking through the imposition of additional fees on withdrawals and deposits made within the branches and through the employees of the bank.

2. The need for all employees at the Bank to be informed about the global developments in the field of Islamic banking through their participation in international conferences and training courses on the development of Islamic products.

3. The need for the Palestinian Monetary Authority to adopt the role of guide for the Islamic banking in Palestine by holding educational workshops on Islamic banking and its modern financing tools.

4. The need to update the regulations and instructions governing the Islamic banking continuously in line with the modern standards of Islamic banking.

5. Establishing clear mechanisms for the implementation of Islamic financing formulas, in coordination between the Sharia Supervisory Board and the Executive Management of Banks.

6. Enhancing the role of the Sharia Supervisory Board in ensuring the implementation of the Islamic financing formulas in accordance with its pre-vision on Islamic tools and services.

7. The need for cooperation and coordination between the Sharia Supervisory Boards of the 
banks on the one hand and the unified body that is affiliated with the Palestinian Monetary Authority, in order to consolidate the legal opinions on the Islamic financial instruments and services.

8. The need to establish special sections dealing with financial engineering in Islamic banks operating in Palestine.

\section{References}

Bonakab, Mokhtar. (2017). The Role of Islamic Financial Engineering in Risk Management of Islamic Financing Formulations - A Case Study of Al Baraka Aljazairy Bank. Algerian Journal of Economic Development, University of Qasidi Marbah, Algeria, Issue 5.

Suwailam, Sami. (2004). The Financial Engineering Industry Looks at the Islamic Approach. Research Center, Al Rajhi Banking Investment Company, 165.

Sabrina, Buteba, Rashad, Mardasi,(2017). Islamic Financial Engineering as a Mechanism for the Provision of Islamic Banking Financing. Journal of Economics of Business and Finance, Institute of Economic and Commercial Sciences, University Center Abdelhafeez Boulosouf, Mila, Algeria, No. 2.

Othman, Abdelkawi Mohamed. (2008). The Use of Financial Engineering in Islamic Banks (Modern Financial Instruments). 3rd Conference of Islamic Banks and Financial Institutions, Damascus.

Ali, Hamza and Abdul Rahman. (2013). The Shari'a Controls for the Use of Financial Engineering as an Approach to the Development of Islamic Financial Products. 2nd International Islamic Financial Industry Forum.

Kunduz, Abdul Karim. (2007). Islamic Financial Engineering. Journal of Islamic Economics, 20(2), 10. King Abdul Aziz University.

Moanis, Raed Nasri. (2016). Rules of Engineering of Islamic Financial Products Analytical Study. Journal of Sharia and Law Studies, 43(1). Faculty of Sharia, University of Jordan, Jordan.

Omrana, Siham, \& Aboulaich, Rajae. (2016). Islamic Financial Engineering Al Arboun Sale. International Journal of Applied Engineering Research, 11(8), 5584-5590. ISSN 0973-4562.

Seng Kiong Kok, Gianluigi Giorgioni, \& Jason Laws. (2014). Derivative products and innovation in Islamic finance: A hybrid tool for risk-sharing options. International Journal of Islamic and Middle Eastern Finance and Management, 7(3), 242-257. https://doi.org/10.1108/IMEFM-07-2013-0084

Ginanjar, Adhitya. Islamic Financial Engineering: Comparative Study Agreements in Islamic Capital Market in Malaysia and Indonesia. Tazkia Islamic Finance and Business Review journal, 8(1).

Al Suwailem, Sami. (2007). Financial Engineering: An Islamic Perspective. KA JIAN BISNIS DAN MANAJEMEN, 9(1), 87-102. 


\section{Macrothink}

Asian Journal of Finance \& Accounting ISSN 1946-052X 2018, Vol. 10, No. 2

Iqbal, Zamir. (1999). Financial Engineering in Islamic Finance. Second Harvard University Forum on Islamic Finance: Islamic Finance into the 21st Century Cambridge, Massachusetts. Center for Middle Eastern Studies, Harvard University. pp.229-238. https://doi.org/10.1002/tie.4270410414 